\title{
Effects of organochlorines on cytochrome P450 activity and antioxidant enzymes in liver of roundnose grenadier Coryphaenoides rupestris
}

\author{
Benjamin Lemaire ${ }^{1, *}$, Imants G. Priede ${ }^{2}$, Martin A. Collins ${ }^{3}$, David M. Bailey ${ }^{4}$, \\ Nicolas Schtickzelle ${ }^{5}$, Jean-Pierre Thomé ${ }^{6}$, Jean-François Rees ${ }^{1}$ \\ ${ }^{1}$ Institut des Sciences de la Vie, Université catholique de Louvain, Croix du Sud 2, 1348 Louvain-la-Neuve, Belgium \\ ${ }^{2}$ Oceanlab, University of Aberdeen, Newburgh, Aberdeenshire AB41 6AA, UK \\ ${ }^{3}$ Government of South Georgia \& South Sandwich Islands, Government House, Stanley FIQQ 1ZZ, Falkland Islands \\ ${ }^{4}$ Faculty of Biomedical and Life Sciences, University of Glasgow, Glasgow, G12 8JU, United Kingdom \\ ${ }^{5}$ Biodiversity Research Centre, Université catholique de Louvain, Croix du Sud 5, 1348 Louvain-la-Neuve, Belgium \\ ${ }^{6}$ Laboratoire d'Ecologie animale et d'Ecotoxicologie, Université de Liège, Institut de chimie, Bâtiment B6c, Allée du 6 Août 15, \\ 4000 Liège, Belgium
}

\begin{abstract}
Oceans function as a sink for organochlorine compounds (OCs) such as PCBs and DDTs. Deep-sea fish bioaccumulate OCs to levels 10 to 100 times higher than shallow-water species. OCs induce the cytochrome P450 (CYP) system, the activity of which may increase reactive oxygen species (ROS) production in liver cells. However, the susceptibility of fish to the oxidative stress likely caused by OCs remains unclear. We analysed whether PCB and DDT contamination of roundnose grenadier Coryphaenoides rupestris was associated with higher ethoxyresorufin-O-deethylase (EROD) activity (CYP1A-related), and activities of antioxidant enzymes such as catalase (CAT), superoxide dismutases (SOD) and glutathione peroxidases (GPX). Biological parameters affecting EROD patterns (e.g. gender, ontogeny) were also investigated. Citrate synthase (CS) was used as a proxy for oxidative metabolism, responsible for basal ROS production and recruitment of antioxidant enzymes in liver cells. Hepatic OC levels were determined in individuals of different sizes (89 to $2016 \mathrm{~g}$ ) from northern Atlantic slopes (depth range $=1000$ to $1900 \mathrm{~m}$ ). Median PCB and DDT values were 2.39 and $1.48 \mathrm{\mu g} \mathrm{g}^{-1}$ lipid weight, respectively, while median EROD activity was $15 \mathrm{pmol} \mathrm{min}^{-1}$ $\mathrm{mg}^{-1}$ protein. Gender greatly influenced OC levels (females were less contaminated), whilst weight (linked to ontogeny) positively affected DDT levels. EROD increased with PCB levels, and to some extent SOD and CAT were more influenced by EROD than CS, indicating that PCBs strongly affect the redox balance of roundnose grenadier liver cells through increased CYP1A activity. Therefore, OC-related CYP1A induction may be a major source of cellular ROS in liver of roundnose grenadier.
\end{abstract}

KEY WORDS: Deep-sea fish · Cytochrome P450 - EROD · PCBs · DDTs · Antioxidant enzymes

\section{INTRODUCTION}

PCBs and DDTs are organochlorine compounds (OCs) which were extensively used in industry and agriculture during the second part of the 20th century (Safe 1994, Morisawa et al. 2002). Due to their high chemical resistance, they tend to persist and concentrate in eco- systems. Although it is far away from the sources of these pollutants, the deep-sea acts as a sink for PCBs and DDTs (Froescheis et al. 2000, Looser et al. 2000). In a pioneering study, Krämer et al. (1984) revealed a strong hepatic bioconcentration of PCBs and DDTs in black scabbard fish Aphanopus carbo, reaching levels 500 times higher than in the shallow water species Spari- 
soma cretense. Since then, several studies have confirmed the occurrence of very high OC levels in deep-sea fish (e.g. Berg et al. 1997, Lee et al. 1997, Solé et al. 2001). This contamination reflects that, once adsorbed on marine snow, these highly lipophilic compounds are brought to the deep-sea floor (Tanabe \& Tatsukawa 1983), where animals characterised by a high longevity and a high trophic level, as is the case for most deep-sea fish, accumulate high levels of OCs in their tissues as they grow. The relationship between depth and OC levels has rarely been investigated on model deep-sea fish species (e.g. Mormede \& Davies 2003).

OCs induce cellular damage in aquatic organisms (e.g. Regoli et al. 2003, Ferreira et al. 2005). Among toxicity mechanisms, oxidative stress, defined as an imbalance between pro-oxidant and antioxidant cellular forces, causes oxidative damage to tissues. This occurs mainly in the endoplasmic reticulum of liver cells, where cytochrome P450 (CYP) activities may generate reactive oxygen species (ROS) as byproducts of detoxification processes (Halliwell \& Gutteridge 1999). ROS can inflict irreversible damage to cell constituents, either lethal or carcinogenic. In OC-contaminated organisms, CYP1A expression is increased, which tends to elevate ROS levels in cells (Schlezinger et al. 2000). This ROS production adds on to that of the mitochondrial electron transport chain (Cadenas \& Davies 2000). To cope with this, organisms possess enzymatic antioxidant defences such as catalase (CAT), superoxide dismutases (SOD) and glutathione peroxidases (GPX). These enzymatic activities are frequently investigated as potential biomarkers in OC-contaminated fish (van der Oost et al. 2003). Increasing hepatic levels of SOD, CAT and GPX in response to OC contamination has been observed in marine fish species (e.g. Rodriguez-Ariza et al. 1993).

In deep-sea fish, low levels of SOD and GPX have been reported and linked to the reduction of oxidative metabolism with depth (Janssens et al. 2000), which raises questions on the ability of these organisms to upregulate antioxidant enzyme synthesis in response to OC contamination. So far, little information is available on the oxidative effect of OC. Porte et al. (2000) analysed hepatic antioxidant enzymes activities and OC levels in muscles of Coryphaenoides guentheri, Lepidion lepidion and Bathypterois mediterraneus individuals sampled in the Mediterranean Sea (1500 to $1800 \mathrm{~m}$ ). The reported OC levels were low and, overall, little differences were reported between sampling sites for both contamination levels and antioxidant enzymatic activities.

To investigate whether the activities of antioxidant enzymes could be linked to OC levels and CYP1A activity in deep-sea fish, we focused our study on the roundnose grenadier Coryphaenoides rupestris, a ben- thopelagic Macrouridae species found on continental slopes of the northern Atlantic Ocean (Merrett \& Haedrich 1997). This generalist feeder is a top predator species of demersal communities (Mauchline \& Gordon 1985), living more than 50 yr (Kelly et al. 1997) and therefore highly prone to OC bioaccumulation. We analysed hepatic levels of PCBs and DDTs, along with related antioxidant enzymes and CYP1A activities of a large number of individuals sampled at a single location and encompassing a large size (and hence age) range. This allowed us to work on livers with significant variation in OC contamination levels. Since antioxidant enzymatic activity levels tend to be adjusted to the intensity of oxidative metabolism in deep-sea fish (Janssens et al. 2000), and as this is affected by the size of the fish (Siebenaller et al. 1982, Bailey et al. 2005), citrate synthase (CS) was used as a proxy for aerobic metabolism, responsible for the basal ROS production in liver cells.

\section{MATERIALS AND METHODS}

Sampling. Roundnose grenadier individuals were caught with an otter trawl semi-balloon net in the Porcupine Sea Bight (1000 to $1900 \mathrm{~m}$ ) during RRS Discovery cruises 250, 252, 260 and 266 (September 2000 to September 2002; Fig. 1). Once on board, animals were transferred into a cold room. Individuals were weighed $( \pm 0.1 \mathrm{~g})$ and stages of gonad maturity (I, $\mathrm{II}=$ immature $;$ III = maturing $; \mathrm{IV}=$ mature $; \mathrm{V}=$ spawning; $\mathrm{VI}=$ spent) were recorded in accordance with Gordon (1979). Liver samples were taken and immediately frozen $\left(-70^{\circ} \mathrm{C}\right)$ until analysis.

OC analysis. A total of 22 PCB congeners (IUPAC nos. $\underline{28}, 44, \underline{52}, 66,70,95, \underline{101}, 110, \underline{118}, 128, \underline{138}, 149$, $\underline{153}, 156,170, \underline{180}, 183,187,194,195,206,209)$, selected for their occurrence in Aroclor ${ }^{\circledR} 1254$ and 1260 mixtures, were analysed (ICES 7 PCBs are underlined). Quantification of PCBs on liver samples was performed as described for grey seal milk samples in Debier et al. (2003), with the following modifications: about $250 \mathrm{mg}$ of liver tissue was used for the simultaneous quantification of PCBs and DDTs ( $p-, p^{\prime}$-[DDT, DDD, DDE]). Lipid extraction was performed with $n$-hexane (twice for each sample) using a Dionex 200 accelerated solvent extractor. Extracts, cleaned-up by a 2-step protocol as described in Debier et al. (2003), were submitted to gas chromatography-electron capture detection (GC-ECD) analysis (Thermo Quest, Trace 2000). This was performed with a ${ }^{63} \mathrm{Ni}$ electron capture detector and an RTX-5ms (30 m $\times 0.25 \mathrm{~mm}, 0.25 \mu \mathrm{m}$ film) capillary column (Restek). Chromatograms were then converted to contamination levels (detection limits $=2 \mathrm{ng} \mathrm{g}^{-1}$ lipid weight) with ChromCard software 4.0 using a linear 


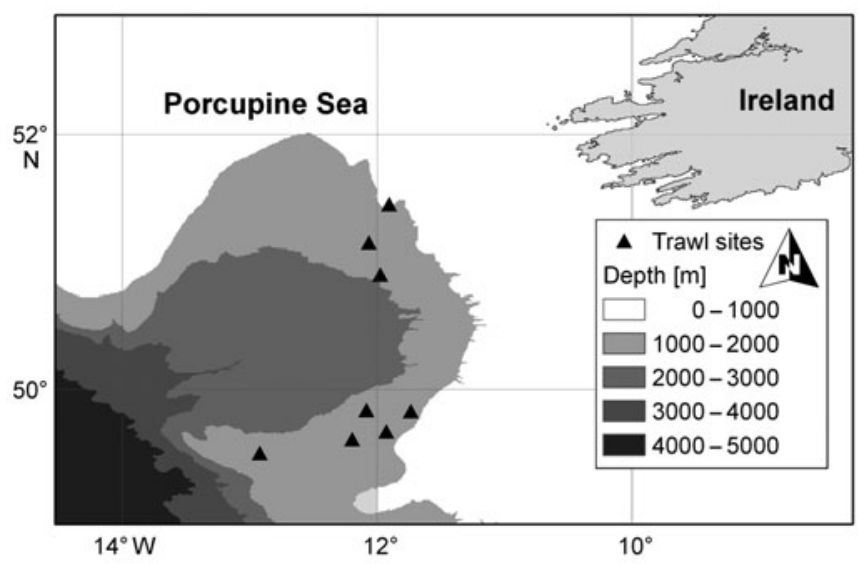

Fig. 1. Sampling sites of roundnose grenadier individuals in the Porcupine Sea Bight

calibration curve of PCB and DDT standards. Quality control for method accuracy was performed by regular analyses of procedural blanks ( $n$-hexane) and standard reference material SRM 1946 (consisting of Lake Superior fish tissue samples) and BCR RM 349 (cod liver), which were obtained from the National Institute of Standards and Technology (USA) and run every 10 samples analyzed. Laboratory-made quality controls, consisting of milk cream to which defined concentrations of PCBs and pesticides were added, were used to control the quality of extraction and clean-up procedures. Recovery efficiencies were corrected from that of

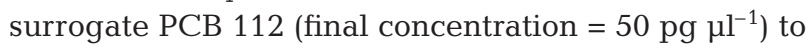
obtain $100 \%$ efficiency. Samples were kept for analysis only if recovery was in the range of 70 to $130 \%$.

EROD measurement. Ethoxyresorufin-O-deethylase (EROD) measurement, based on the method of Burke \& Mayer (1974), was adapted in the lab for deep-sea fish samples. Frozen liver sections (about $500 \mathrm{mg}$ ) were homogenised in $1 \mathrm{ml}$ of $100 \mathrm{mM} \mathrm{Na} \mathrm{HPO}_{4} / \mathrm{KH}_{2} \mathrm{PO}_{4}$ buffer ( $\mathrm{pH} 7.8$ ) containing $20 \%$ glycerol and $0.2 \mathrm{mM}$ phenylmethylsulfonyl fluoride. Homogenates were then centrifuged for $20 \mathrm{~min}$ at $9000 \times g\left(4^{\circ} \mathrm{C}\right)$. Supernatants, collected in cryotubes, were first stored at $-20^{\circ} \mathrm{C}$ for $30 \mathrm{~min}$ and then transferred to liquid nitrogen. On the day of measurement, S9 fractions were thawed and protein contents determined (see below). Samples were diluted in $100 \mathrm{mM} \mathrm{Na} 2 \mathrm{HPO}_{4} / \mathrm{KH}_{2} \mathrm{PO}_{4}$ buffer ( $\mathrm{pH} \mathrm{7.4)}$ to $5,2.5$ and $1.25 \mathrm{mg}$ proteins $\mathrm{ml}^{-1}$. NADPH $(2.5 \mathrm{mM})$ started the reaction at $25^{\circ} \mathrm{C}$. The conversion of 7 -ethoxyresorufin $(2 \mu \mathrm{M})$ to resorufin was measured for 6 min using a Fluoroskan Ascent (Labsystems) with excitation and emission wavelengths of 530 and $590 \mathrm{~nm}$. A standard curve of resorufin $\left(\varepsilon=73.2 \mathrm{mM}^{-1} \mathrm{~cm}^{-1} ; 572 \mathrm{~nm}\right)$ was performed on each 96 well plate.

Measurement of antioxidant enzymes. Liver tissues (100 mg) were homogenised in $500 \mu \mathrm{l}$ phosphate buffered saline (PBS) containing 1\% Triton X-100 ( $\mathrm{pH} 7.4)$. Before centrifugation $(15000 \times g$ for $10 \mathrm{~min}$ at $\left.4^{\circ} \mathrm{C}\right), 10 \mu \mathrm{l}$ homogenates were removed for protein content determination (DC-Protein Assay Kit, Bio-Rad) against a standard curve of bovine serum albumin. Antioxidant enzyme assays were performed on supernatants in 96 well plates $\left(25^{\circ} \mathrm{C}\right)$, either on a luminometer (LB96 P, Berthold) or a spectrophotometer (Spectramax 190, Molecular Devices).

CAT activity was determined with a luminescencebased method for the quantification of $\mathrm{H}_{2} \mathrm{O}_{2}$ that was adapted by Janssens et al. (2000). Briefly, samples were diluted in $100 \mathrm{mM} \mathrm{Na} \mathrm{HPO}_{4} / \mathrm{NaH}_{2} \mathrm{PO}_{4}$ buffer (pH 7.8) containing 0.6 mM EDTA. Injections of $\mathrm{H}_{2} \mathrm{O}_{2}$ $(10 \mu \mathrm{M})$ and a mixture of luminol $(20 \mathrm{mM})$ and horseradish peroxidase $\left(11.6 \mathrm{U} \mathrm{ml}^{-1}\right)$ were performed at 30 min intervals. A standard curve was prepared with bovine catalase.

SOD activity was quantified in accordance with McCord \& Fridovich (1969). Samples were diluted in $50 \mathrm{mM} \mathrm{Na} \mathrm{HPO}_{4} / \mathrm{NaH}_{2} \mathrm{PO}_{4}$ buffer ( $\mathrm{pH}$ 7.8) containing $0.5 \mathrm{mM}$ EDTA. The assay is based on the competition between SOD and ferricytochrome C ( $2 \mu \mathrm{M})$ for superoxide anions generated by xanthine oxidase $\left(0.2 \mathrm{U} \mathrm{ml}^{-1}\right)$ and hypoxanthine $(5 \mu \mathrm{M})$. Production of ferrocytochrome $\mathrm{C}$ was followed at $550 \mathrm{~nm}\left(\varepsilon=9245 \mathrm{M}^{-1} \mathrm{~cm}^{-1}\right)$ and an inhibition curve was performed with $\mathrm{Cu} / \mathrm{Zn}$-SOD from bovine erythrocytes (one enzymatic unit corresponding to $50 \%$ inhibition of ferrocytochrome $\mathrm{C}$ production).

GPX activity was adapted for use on 96 well plates from the method of Paglia \& Valentine (1967). Samples were diluted in $50 \mathrm{mM}$ Tris/ $\mathrm{HCl}$ buffer ( $\mathrm{pH}$ 7.6) containing $0.1 \mathrm{mM}$ EDTA. A mixture of glutathione reductase (12.5 U), NADPH (0.14 mM) and GSH (1 mM) was prepared with this buffer. $\mathrm{H}_{2} \mathrm{O}_{2}$ or tert-butyl hydroperoxide (tBHP) were used as substrates $(0.3 \mathrm{mM})$ to quantify the contribution of seleno-dependent $\left(\mathrm{GPX}_{\mathrm{H}}\right)$ and seleno-independent $\left(\mathrm{GPX}_{\mathrm{T}}\right)$ subfamilies. The disappearance of NADPH $\left(\varepsilon=2160 \mathrm{M}^{-1} \mathrm{~cm}^{-1}\right)$ was followed at $340 \mathrm{~nm}$.

Citrate synthase (CS) activity was determined on 96 well plates in accordance with Bailey et al. (2005). Samples were diluted in $100 \mathrm{mM}$ Tris/ $\mathrm{HCl}$ buffer ( $\mathrm{pH}$ 8). A solution of acetylcoenzyme A $(200 \mu \mathrm{M})$ and 5,5'-dithio-bis-2-nitrobenzoic acid (DTNB, $100 \mu \mathrm{M}$ ) was added to the wells. Oxaloacetate $(500 \mu \mathrm{M})$, prepared in the same buffer, started the reaction. Conversion of DTNB to 5-thio-2-nitrobenzoate (TNB, $\varepsilon=$ $4928 \mathrm{M}^{-1} \mathrm{~cm}^{-1}$ ) was followed at $412 \mathrm{~nm}$.

Statistical analyses. Data analysis consisted of linear regressions aimed at determining, among a series of relevant explanatory variables, those with the highest power to explain the variations in a response variable and also to estimate the size of these effects. Due to multicollinearity between the biological variables in- 
vestigated, a multi-model inference approach, based on corrected Akaike's information criterion $\left(\mathrm{AIC}_{\mathrm{c}}\right)$, was chosen. This statistical method consists of several steps (see Anderson 2008, Burnham \& Anderson 2008). (1) Linear regression models which correspond to all possible combinations of explanatory variables were fitted to the data. (2) The power of each model to explain existing variations in the response variable was assessed through the $\mathrm{AIC}_{\mathrm{c}}$ value. (3) The relative importance of each explanatory variable was quantified through its $\mathrm{AIC}_{\mathrm{c}}$ weight (computed as the sum of the $\mathrm{AIC}_{\mathrm{C}}$ weight of all models where this explanatory variable appears). Those variables having the largest $\mathrm{AIC}_{\mathrm{C}}$ weight predominantly affect the response variable. There is no cut-off significance level, as this would be contrary to the philosophical grounds of this approach, which aims at giving the reader a quantification of the importance of an effect (each reader being free to draw conclusions from it). This methodology is not associated to hypothesis testing or p-values. (4) Multimodel averaged estimates of the beta parameter and its standard error were computed as a weighted mean of estimates given by each model, each estimate being weighted by the $\mathrm{AIC}_{\mathrm{c}}$ weight of the model. If a variable is absent in a given model, it has zero values for beta, i.e. we used the so-called 'shrinkage approach' to model averaging.

Three relationships were investigated: (1) PCB and DDT levels as a function of gender, depth of catch and weight of roundnose grenadier individuals; (2) CYP1A activity according to the level of PCB and DDT contamination - a quadratic response was investigated because we assumed that high OC levels could lead to CYP1A inhibition (Petrulis \& Bunce 1999) — by gender and maturity level, as physiological processes such as hormone biosynthesis and degradation could greatly influence CYP activities (e.g. Goksoyr \& Förlin 1992); and (3) antioxidant enzymatic activities according to EROD and CS activity, the latter used as a proxy for oxidative metabolism (Janssens et al. 2000).

\section{RESULTS}

\section{Sampling and data description}

A total of 51 roundnose grenadier individuals, caught over a 2 yr period, were used in the present study. Samples of both males $(\mathrm{n}=20)$ and females $(\mathrm{n}=31)$ were used. Emphasis was put on sampling individuals covering a wide size range (body weight $=89$ to $2016 \mathrm{~g}$ ), so as to include most of the ontogeny of this species of Macrouridae. According to the sex-specific plots of weight versus age in roundnose grenadier individuals obtained by Kelly et al. (1997), the speci- mens selected in the present study may well vary between 0 and $40 \mathrm{yr}$ old.

A total of 42 samples were sufficiently large to provide enough material for OC analysis. The livers analysed had high lipid contents $(34.7 \pm 11.1 \%)$ and were heavily contaminated by PCB congeners and DDTs. The median $\Sigma$ PCB value for the entire popula-

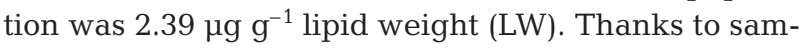
ple selection (designed to obtain a considerable range of body weights, and hence ages), large variability was found in the hepatic $\Sigma$ PCB content of individuals, ranging from 0.71 to $14.06 \mu \mathrm{g} \mathrm{g}^{-1} \mathrm{LW}$. Fig. 2 gives the PCB congener contamination levels: overall, penta-chlorinated congeners (18\%), hexa-chlorinated congeners $(45 \%)$ and hepta-chlorinated congeners (27\%) were the dominant classes. Normalisation of the PCB congener levels to that of PCB 153 allowed comparison of the global pattern with Aroclor 1254 and 1260 mixtures. By doing so, a closer resemblance to the Aroclor 1260 mixture was observed, due to a relatively high content of hepta- and octo-chlorinated congeners in the samples. Hepatic levels of DDTs were also elevated, with a median $\Sigma$ DDT value of $1.48 \mu \mathrm{g} \mathrm{g}^{-1} \mathrm{LW}$ for the entire population. Variability between individuals was also high in that case, with $\Sigma$ DDT ranging from 0.18 to $4.92 \mathrm{\mu g} \mathrm{g}^{-1} \mathrm{LW}$. DDE accounted for $63 \%$ of $\Sigma$ DDT contamination, DDD contributed $15 \%$ and DDT $22 \%$ (data not shown).

\section{Hepatic OC levels}

Hepatic levels of $\Sigma$ PCB differed between genders, with females being less contaminated than males. There is only low support for an effect of depth of catch and weight of individuals on hepatic $\Sigma$ PCB levels (Table 1).

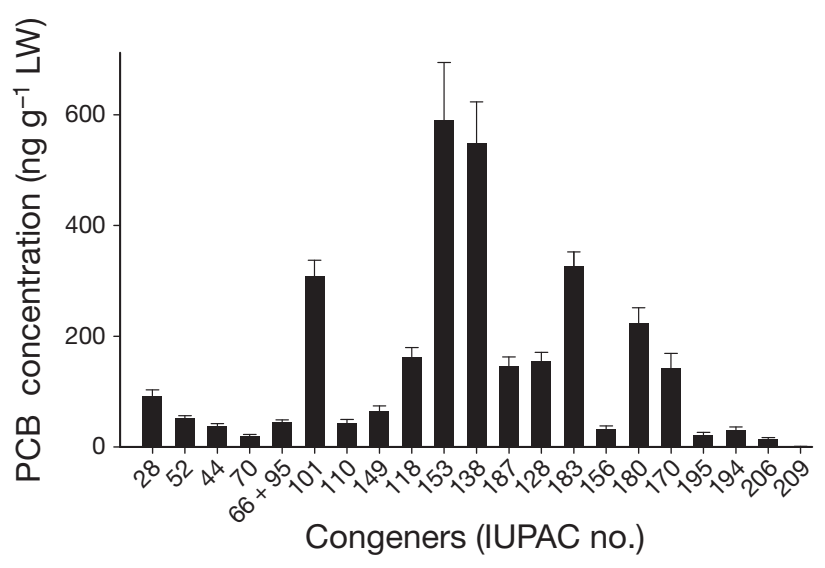

Fig. 2. Coryphaenoides rupestris. Levels of PCB congeners (ng $\mathrm{g}^{-1}$ lipid weight) in roundnose grenadier liver. Results are mean \pm SE. PCB 66 and PCB 95 were not separated during gas chromatography-electron capture detection analysis 
As for $\Sigma \mathrm{PCB}$, gender seemed decisive in the determination of $\Sigma D D T$ levels (Table 1), with females being less contaminated. However, contrary to what was found for $\Sigma \mathrm{PCB}$, a first-order age-dependent increase in hepatic $\Sigma$ DDT levels was also observed, with much higher support than was the case for $\Sigma \mathrm{PCB}$. Depth of catch seemed to have little effect.

\section{Determinants of EROD activity}

\section{Influence of $\Sigma \mathrm{PCB}$}

When considering the effects of $\Sigma \mathrm{PCB}$, gender and gonad maturity on EROD levels, a dominant effect of $\Sigma \mathrm{PCB}$ and a negative effect of gonad maturity were found (Table 2). A quadratic component in the effect of $\mathrm{PCB}$ also had strong support (suggesting a bellshaped pattern of EROD as a function of $\Sigma$ PCB), but this effect (and only this one) was mitigated when the single most contaminated individual was removed from the data set $\left(\mathrm{AIC}_{\mathrm{c}}=0.52\right.$ instead of 0.84$)$. Gender by itself seemed to have a low impact on EROD activity. However, the maturity groups as defined in the present study (mature females versus immature females and males) probably comprised an important part of the effect of gender per se. Fig. 3 represents the scatter plot of the relationship between $\Sigma \mathrm{PCB}$ and EROD in the entire population. The same analysis using a subset of 7 representative PCB congeners (ICES $7 ; \Sigma_{7} \mathrm{PCB}$ ) instead of $\Sigma$ PCB led to similar results (data not shown).

Table 1. Multi-model inference of the effects of depth of catch $(\mathrm{m})$, weight of individuals $(\mathrm{g})$ and sex on hepatic PCB and DDT levels (ng ${ }^{-1}$ lipid weight) in roundnose grenadier Coryphaenoides rupestris. $\mathrm{AIC}_{\mathrm{c}}$ weight represents the relative importance of variables explaining variation in the response variables. Explanatory variables were standardized to allow direct comparison of beta parameters

\begin{tabular}{|lccc|}
\hline Variable & AIC $_{\mathrm{c}}$ weight & Beta & $\mathrm{SE}$ \\
\hline $\boldsymbol{\Sigma P C B}$ & & & \\
Intercept & 1.00 & 4043.41 & 695.74 \\
Depth & 0.44 & 226.50 & 203.03 \\
Weight & 0.30 & 98.15 & 129.45 \\
Sex & & & \\
Female & 0.78 & -1338.07 & 648.41 \\
Male & 0.78 & 0 & - \\
$\boldsymbol{\Sigma D D T}$ & & & \\
Intercept & 1.00 & 2261.74 & 274.53 \\
Depth & 0.33 & 49.65 & 58.64 \\
Weight & 0.82 & 279.18 & 126.13 \\
Sex & & & \\
Female & 0.92 & -786.35 & 287.18 \\
Male & 0.92 & 0 & - \\
\hline
\end{tabular}

\section{Influence of $\Sigma \mathrm{DDT}$}

When EDDT was used to explain EROD levels, results were similar to those with $\Sigma \mathrm{PCB}$, except that there was low support for a quadratic component in the

Table 2. Multi-model inference of the effects of hepatic organochlorine (OC) levels (PCBs or DDTs, ng g ${ }^{-1}$ lipid weight), their quadratic mode of expression $\left(\mathrm{OC}^{2}\right)$ and biological status (sex, maturity of females) on ethoxyresorufin-Odeethylase (EROD) levels in roundnose grenadier Coryphaenoides rupestris. $\mathrm{AIC}_{\mathrm{c}}$ weight represents the relative importance of the variable explaining variation in the response variables. Explanatory variables were standardized to allow direct comparison of beta parameters. Results obtained when the most strongly PCB-contaminated individual was removed from the data set are in parentheses

\begin{tabular}{|lccc|}
\hline Variable & AIC $_{\mathrm{c}}$ weight & Beta & $\mathrm{SE}$ \\
\hline $\boldsymbol{\Sigma}$ PCB & & & \\
Intercept & 1.00 & $13.54(13.17)$ & 3.19 \\
OC & $0.98(0.89)$ & $11.15(8.56)$ & $4.15(5.28)$ \\
OC & $0.84(0.52)$ & -7.15 & $3.17(4.47)$ \\
Sex & & & \\
Female & 0.22 & 0.22 & $0.76(0.78)$ \\
Male & 0.22 & 0 & - \\
Mature females & $0.83(0.85)$ & $-6.09(-6.27)$ & $2.59(2.61)$ \\
Other individuals & $0.83(0.85)$ & 0 & - \\
& & & \\
$\boldsymbol{\Sigma}$ DDT & 1.00 & 12.17 & 3.05 \\
Intercept & 0.91 & 6.69 & 3.66 \\
OC & 0.49 & -2.36 & 2.93 \\
OC & & & \\
Sex & & 0.27 & 0.81 \\
Female & 0.23 & 0 & - \\
Male & 0.23 & 7.31 & 2.67 \\
Mature females & 0.91 & 0 & - \\
Other individuals & 0.91 & & \\
\hline
\end{tabular}

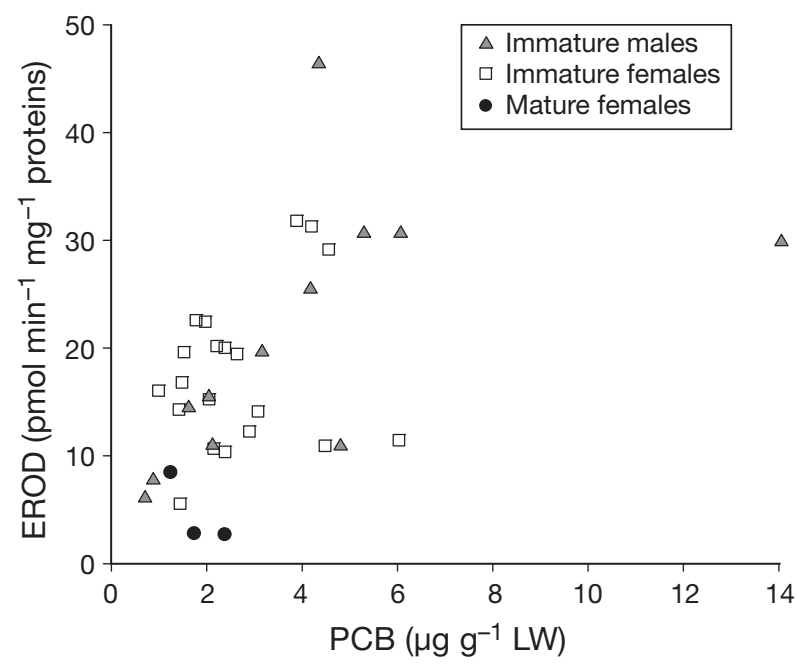

Fig. 3. Coryphaenoides rupestris. Relationship between $\Sigma$ PCB levels ( $\mathrm{g} \mathrm{g}^{-1}$ lipid weight) and ethoxyresorufin-O-deethylase (EROD) activity (pmol min ${ }^{-1} \mathrm{mg}^{-1}$ proteins) in liver 
effect of $\Sigma D D T$ on EROD, as was the case for the effect of $\Sigma$ PCB when the outlier individual was removed from the data set (Table 2).

\section{Determinants of antioxidant enzyme activities}

SOD and CAT activities were predominantly and positively affected by EROD, whilst CS (an oxidative metabolism proxy) had a far less important effect on those antioxidant enzyme activities. Neither EROD nor CS activities seemed to explain the observed patterns of GPX activity (Table 3). Such a result could partly be due to the low number of samples analysed and the low variability of GPX activities found in samples. Scatter plots of the relationships between EROD and SOD and between EROD and CAT in the population are shown in Fig. 4.

\section{DISCUSSION}

High levels of PCBs and DDTs have been previously recorded in tissues of several deep-sea fish species. However, due to difficulties in sampling, previous studies have been generally based on limited numbers of individuals of similar size, showing little variation in OC contamination levels (e.g. Berg et al. 1998, Porte et al. 2000) that could influence CYP and antioxidant enzyme activities. We overcame these limitations by focusing our efforts on a single species caught in large numbers at different depths within a limited area. A large size range of individuals was selected as this

Table 3. Multi-model inference of the effects of hepatic oxidative metabolism (CS, $\mathrm{U} \mathrm{g}^{-1}$ wet weight) and CYP1A activity (EROD, pmol min $\mathrm{mg}^{-1}$ protein) on superoxide dismutases (SOD), catalase (CAT) and glutathione peroxidases (GPX) activity ( $\mathrm{U} \mathrm{g} \mathrm{g}^{-1}$ wet weight) in roundnose grenadier Coryphaenoides rupestris. $\mathrm{AIC}_{c}$ weight represents the relative importance of the variable explaining variation in the response variables. Explanatory variables were standardized to allow direct comparison of beta parameters

\begin{tabular}{|lccc|}
\hline Variable & AIC $_{\mathrm{c}}$ weight & Beta & $\mathrm{SE}$ \\
\hline SOD & & & \\
Intercept & 1.00 & 404.32 & 43.35 \\
CS & 0.23 & 2.67 & 11.43 \\
EROD & 0.89 & 106.53 & 40.81 \\
CAT & & & \\
Intercept & 1.00 & 22360 & 2436 \\
CS & 0.42 & 1567 & 1434 \\
EROD & 0.86 & 5660 & 2343 \\
GPX & & & \\
Intercept & 1.00 & 0.46 & 0.08 \\
CS & 0.32 & -0.03 & 0.03 \\
EROD & 0.22 & 0.01 & 0.02 \\
\hline
\end{tabular}
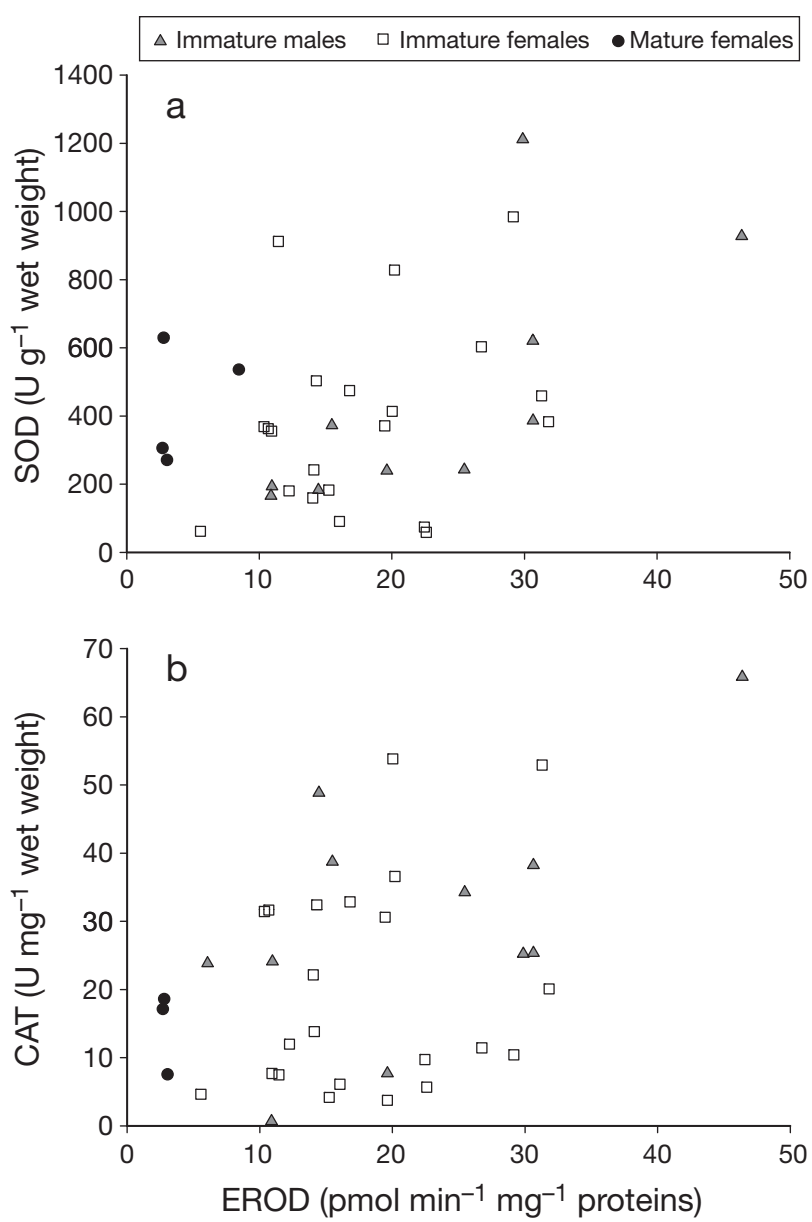

Fig. 4. Coryphaenoides rupestris. Relationship between hepatic ethoxyresorufin-O-deethylase (EROD) activity (pmol $\mathrm{min}^{-1} \mathrm{mg}^{-1}$ protein) and activity of the antioxidant enzymes (a) superoxide dismutases ( $\mathrm{SOD}, \mathrm{U} \mathrm{g}^{-1}$ wet weight) and (b) catalase (CAT, $\mathrm{U} \mathrm{mg}^{-1}$ wet weight)

generated data covering a large scale of contamination levels, over 1 order of magnitude. This facilitated a discriminatory study on the impact of these xenobiotics on EROD and antioxidant enzymes. Moreover, sampling both males and females in large numbers between 1000 and $1900 \mathrm{~m}$ allowed the effects of gender and depth to be investigated.

PCB and DDT levels recorded in the present study were of the same magnitude as in previous studies on roundnose grenadier and other deep-sea fish (e.g. Berg et al. 1997, 1998, Solé et al. 2001, Mormede \& Davies 2003). We confirmed the prevalence of highly chlorinated PCB congeners in the deep sea (Tanabe \& Tatsukawa 1983), most likely reflecting their lower susceptibility to biodegradation combined with their higher adsorption efficiency on organic matter. Among DDTs, DDE was prevalent, as generally seen in other deepsea fish (Berg et al. 1997, Mormede \& Davies 2003). Indeed, high residence time of the parent compound in 
water allows diverse organisms to metabolise DDT to DDE, leading to an increased DDE:DDT ratio with time. Median CYP1A activity was $15 \mathrm{pmol} \mathrm{min}^{-1} \mathrm{mg}^{-1}$ protein, which is lower than previous reports on microsomal fractions of roundnose grenadier (Förlin et al. 1996, Lindesjöö et al. 1996). Differences probably reflect the use of S9 fractions instead of purified microsomes (Viarengo et al. 2000).

Among antioxidant enzymes, CAT was abundant, which supports the idea that this enzyme is favoured in deep-sea environments to counteract $\mathrm{H}_{2} \mathrm{O}_{2}$ (Janssens et al. 2000). SOD activity was in the range of that found in contaminated coastal fish species (Porte et al. 2002, Ferreira et al. 2005).

Gender was a major determinant of the contamination levels, with females having lower hepatic PCB levels than males (median $=2.38$ and $4.11 \mu^{-1} \mathrm{~g}^{-1} \mathrm{LW}$, respectively), as well as DDT levels (median $=1.26$ and $2.43 \mu \mathrm{g} \mathrm{g}^{-1} \mathrm{LW}$, respectively), a situation already observed for roundnose grenadier caught west of Ireland (Mormede \& Davies 2003). Such differences in the hepatic OC levels are not a consequence of differential lipid contents in livers of males and females. It is therefore possible that females eliminate OC during vitellogenesis, when hepatic lipids are recruited for the huge production of eggs, characteristic of this species (Allain 2001). Depth and weight of individuals were not as important in the explanation of hepatic PCB levels. It has to be stressed that roundnose grenadier may migrate in the water column on a daily basis to feed (Atkinson 1995), and therefore the depth of catch may not fully represent the feeding history of individuals and depth per se may not be a relevant parameter.

In the case of DDTs, the weight of individuals (linked to ontogeny) seemed of primary importance for the determination of hepatic OC levels. This suggests that DDTs bioaccumulate linearly during the development of roundnose grenadier individuals, leading to an age-dependent increase in hepatic levels of DDT. This could reflect, as hypothesized by Mormede \& Davies (2001), that DDTs are resistant to CYP metabolism in deep-sea fish.

The most important results of the present study concern the possible links between OC contamination and the levels of CYP1A-related EROD and antioxidant enzyme activities. Results suggest that PCBs have a positive effect on CYP1A activity. We also observed that mature females had lower EROD levels, probably in response to steroid metabolism (Goksoyr \& Förlin 1992). The apparent major contribution of DDTs in the determination of EROD may simply reflect the similarities in physico-chemical properties of PCBs and DDTs.

Finally, the relationships between the metabolic sources of ROS (oxidative metabolism and CYP1A activity) and antioxidant enzymes activities revealed a major effect of CYP1A levels on SOD and CAT patterns of activity, and a minor contribution of oxidative metabolism. This indicates that higher CYP1A activity increases the need for SOD and CAT in liver cells of roundnose grenadier, at levels that may be well above those needed to counteract ROS produced during cellular respiration.

Liver cells showed increasing EROD levels, probably reflecting the induction of CYP1A by some of the PCB congeners. An increased ROS production by CYP1A activity would require higher SOD and CAT levels, as these were also increased. This could strengthen the cellular resistance towards OC-derived ROS. These are the first data supporting an adaptive increase of cellular antioxidant capacity in response to EROD activation in highly PCB-contaminated deep-sea fish. Whether this response to the contamination could fully prevent OC-related tissue damage remains to be investigated.

Acknowledgements. We thank the captain and crew members of the RRS 'Discovery' cruises 250, 252, 260 and 266, the Fonds de la Recherche Scientifique (FRS FNRS, Belgium) and the Fonds de la Recherche Fondamentale Collective (FRFC, Belgium) for their support. The Fonds pour la Formation à la Recherche dans l'Industrie et dans l'Agriculture (FRIA, Belgium) is also greatly acknowledged for its financial support (PhD fellowship to B.L.). We also thank Tomasz Niedzielski (Oceanlab, Aberdeen) for providing a high resolution map of the trawl stations. N.S. is a research associate of FRS FNRS.

\section{LITERATURE CITED}

Allain V (2001) Reproductive strategies of three deep-water benthopelagic fishes from the northeast Atlantic Ocean. Fish Res 51:165-176

Anderson DR (2008) Model based inference in the life sciences: a primer on evidence. Springer-Verlag, Berlin

Atkinson DB (1995) The biology and fishery of roundnose grenadier (Coryphaenoides rupestris Gunnerus, 1765) in the North West Atlantic. In: Hopper AG (ed) Deep-water fisheries of the North Atlantic oceanic slope. NATO ASI Series, Series E: Applied Sciences, Vol 296, Kluwer, Dordrecht, p 51-111

> Bailey DM, Genard B, Collins MA, Rees JF and others (2005) High swimming and metabolic activity in the deep-sea eel Synaphobranchus kaupii revealed by integrated in situ and in vitro measurements. Physiol Biochem Zool 78:335-346

Berg V, Ugland KI, Hareide NR, Aspholm PE, Polder A, Skaare JU (1997) Organochlorine contamination in deepsea fish from the Davis Strait. Mar Environ Res 44:135-148

Berg V, Polder A, Skaare JU (1998) Organochlorines in deep sea fish from the Nordfjord. Chemosphere 38:275-282

Burke MD, Mayer RT (1974) Ethoxyresorufin: direct fluorimetric assay of a microsomal O-dealkylation which is preferentially inducible by 3-methylcholanthrene. Drug Metab Dispos 2:583-588

Burnham KP, Anderson DR (2008) Model selection and multimodel inference: a practical information-theoretic approach. Springer-Verlag, Berlin

Cadenas E, Davies KJA (2000) Mitochondrial free radical generation, oxidative stress and aging. Free Radic Biol Med 29:222-230 
Debier C, Pomeroy PP, Dupont C, Joiris C and others (2003) Quantitative dynamics of PCB transfer from mother to pup during lactation in UK grey seals Halichoerus grypus. Mar Ecol Prog Ser 247:237-248

Ferreira M, Moradas-Ferreira P, Reis-Henriques MA (2005) Oxidative stress biomarkers in two resident species, mullet (Mugil cephalus) and flounder (Platichtys flesus), from a polluted site in River Douro Estuary, Portugal. Aquat Toxicol 71:39-48

Förlin L, Phil-Baden S, Eriksson S, Granmo A and others (1996) Effects of contaminants in roundnose grenadier (Coryphaenoides rupestris) and Norway lobster (Nephrops norvegicus) and contaminant levels in mussels (Mytilus edulis) in the Skagerrak and Kattegat compared to the Faroë Islands. J Sea Res 35:209-222

Froescheis O, Looser R, Cailliet GM, Jarman WM, Ballschmiter K (2000) The deep-sea as a final global sink of semivolatile persitent organic pollutants? Part 1: PCBs in surface and deep-sea dwelling fish of the North and South Atlantic and the Monterey Bay Canyon (California). Chemosphere 40: 651-660

Goksoyr A, Förlin L (1992) The cytochrome P450 system in fish, aquatic toxicology and environmental monitoring. Aquat Toxicol 22:287-312

Gordon JDM (1979) Seasonal reproduction in deep-sea fish. In: Naylor E, Hartnoll RG (eds) Cyclic phenomena in marine plants and animals. Proc 13th Eur Mar Biol Symp, Pergamon Press, Oxford, p 223-229

Halliwell B, Gutteridge JMC (1999) Free radicals in biology and medicine. Oxford University Press, New York

> Janssens BJ, Childress JJ, Baguet F, Rees JF (2000) Reduced enzymatic antioxidative defense in deep-sea fish. J Exp Biol 203:3717-3725

Kelly CJ, Connolly PL, Bracken JJ (1997) Age estimation, growth, maturity and distribution of the roundnose grenadier from the Rockall Trough. J Fish Biol 50:1-17

Krämer W, Buchert H, Reuter U, Biscoito M, Maul DG, Le Grand G, Ballschmiter K (1984) Global baseline pollution studies IX: $\mathrm{C}_{6}-\mathrm{C}_{14}$ organochlorine compounds in surfacewater and deep-sea fish from the eastern North Atlantic. Chemosphere 13:1255-1267

Lee JS, Tanabe S, Takemoto N, Kubodera T (1997) Organochlorine residues in deep-sea organisms from Suruga Bay, Japan. Mar Pollut Bull 34:250-258

Lindesjöö E, Husoy AM, Petterson I, Förlin L (1996) Histopathological and immunohistochemical studies in roundnose grenadier (Coryphaenoides rupestris) in the Skagerrak, North Sea. Mar Environ Res 42:229-233

Looser R, Froescheis O, Cailliet GM, Jarman WM, Ballschmiter K (2000) The deep sea as a final global sink of semivolatile persistent organic pollutants? Part 2: Organochlroine pesticides in surface and deep-sea dwelling fish of the North and South Atlantic and the Monterey Bay Canyon (California). Chemosphere 40:661-670

Mauchline J, Gordon JDM (1985) Trophic diversity in deepsea fish. J Fish Biol 26:527-535

McCord JM, Fridovich I (1969) Superoxide dismutase. J Biol Chem 244:6049-6055

Merrett NR, Haedrich RL (1997) Deep-sea demersal fish and fisheries. Chapman \& Hall, London

Editorial responsibility: Otto Kinne, Oldendorf/Luhe, Germany
Morisawa S, Kato A, Yoneda M, Shimada Y (2002) The dynamic performances of DDTs in the environment and Japanese exposure to them: a historical perspective after the ban. Risk Anal 22:245-263

Mormede S, Davies IM (2001) Polychlorobiphenyl and pesticide residues in monkfish Lophius piscatorius and black scabbard Aphanopus carbo from the Rockall Trough. ICES J Mar Sci 58:725-736

> Mormede S, Davies IM (2003) Horizontal and vertical distribution of organic contaminants in deep-sea fish species. Chemosphere 50:563-574

Paglia DE, Valentine WN (1967) Studies on the quantitative and qualitative characterisation of erythrocytes glutathione peroxidase. J Lab Clin Med 70:158-168

> Petrulis JR, Bunce NJ (1999) Competitive inhibition by inducer as a confounding factor in the use of the ethoxyresorufin-O-deethylase (EROD) assay to estimate exposure to dioxin-like compounds. Toxicol Lett 105:251-260

> Porte C, Escartin E, Garcia LM, Solé M, Albaigés J (2000) Xenobiotic metabolising enzymes and antioxidant defences in deep-sea fish: relationship with contaminant body burden. Mar Ecol Prog Ser 192:259-266

Porte C, Escartin E, Garcia de la Parra LM, Biosca X, Albaigés J (2002) Assessment of coastal pollution by combined determination of chemical and biochemical markers in Mullus barbatus. Mar Ecol Prog Ser 235:205-216

Regoli F, Winston GW, Gorbi S, Frenzilli G, Nigro M, Corsi I, Focardi S (2003) Integrating enzymatic responses to organic chemical exposure with total oxyradical absorbing capacity and DNA damage in the European eel Anguilla anguilla. Environ Toxicol Chem 22:2120-2129

> Rodriguez-Ariza A, Peinado J, Pueyo C, Lopez-Barea J (1993) Biochemical indicators of oxidative stress in fish from polluted littoral areas. Can J Fish Aquat Sci 50: 2568-2573

> Safe SH (1994) Polychlorinated biphenyls (PCBs): environmental impact, biochemical and toxic responses and implications for risk assessment. Crit Rev Toxicol 24: 87-149

Schlezinger JJ, Keller J, Verbrugge LA, Stegeman JJ (2000) $3,3^{\prime}, 4,4^{\prime}$-tetrachlorobiphenyl oxidation in fish, bird and reptile species: relationship to cytochrome P450 1A inactivation and reactive oxygen production. Comp Biochem Physiol C 125:273-286

> Siebenaller JF, Somero GN, Haedrich RL (1982) Biochemical characteristics of macrourid fishes differing in their depths of distribution. Biol Bull 163:240-249

Solé M, Porte C, Albaigés J (2001) Hydrocarbons, PCBs and DDTs in the NW Mediterranean deep-sea fish Mora moro. Deep-Sea Res I 48:495-513

Tanabe S, Tatsukawa R (1983) Vertical transport and residence time of chlorinated hydrocarbons in the open ocean water column. J Oceanogr Soc Jpn 39:53-62

> van der Oost R, Beyer J, Vermeulen NPE (2003) Fish bioaccumulation and biomarkers in environmental risk assessment: a review. Environ Toxicol Pharmacol 13:57-149

Viarengo A, Lafaurie M, Gabrielides GP, Fabbri R, Marro A, Roméo M (2000) Critical evaluation of an intercalibration exercise undertaken in the framework of the MED POL biomonitoring program. Mar Environ Res 49:1-18

Submitted: July 8, 2008; Accepted: January 27, 2010

Proofs received from author(s): February 12, 2010 